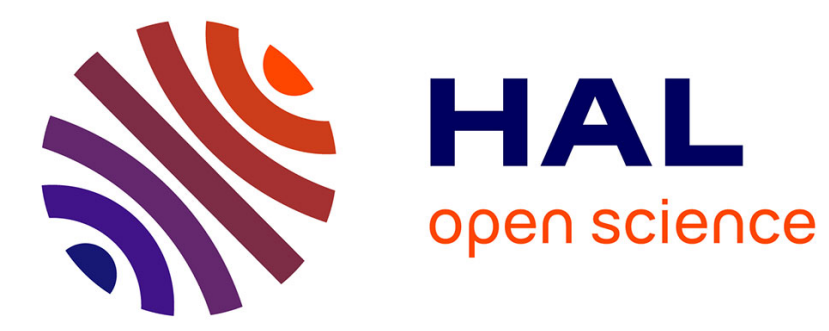

\title{
The Party Conference speech as a genre event: a multimodal approach
}

Emilie L'Hôte, Camille Debras

\section{To cite this version:}

Emilie L'Hôte, Camille Debras. The Party Conference speech as a genre event: a multimodal approach. Genre in Language, Discourse and Cognition, Mouton de Gruyter; De Gruyter, 2016, 9783110467703. 10.1515/9783110469639-015 . hal-01231330

\section{HAL Id: hal-01231330 \\ https://hal-univ-paris.archives-ouvertes.fr/hal-01231330}

Submitted on 15 Jan 2021

HAL is a multi-disciplinary open access archive for the deposit and dissemination of scientific research documents, whether they are published or not. The documents may come from teaching and research institutions in France or abroad, or from public or private research centers.
L'archive ouverte pluridisciplinaire $\mathbf{H A L}$, est destinée au dépôt et à la diffusion de documents scientifiques de niveau recherche, publiés ou non, émanant des établissements d'enseignement et de recherche français ou étrangers, des laboratoires publics ou privés. 


\title{
Emilie L'Hôte and Camille Debras The Party Conference Speech as a genre event: a multimodal approach
}

\begin{abstract}
We analyse British party conference speeches as multimodal genre events (Steen 2011) that aim to provide a privileged platform for dialogue with the British public. Based on a large corpus of recent texts (1994-2013) and the video recording of Tony Blair's 2006 speech to the Labour party conference, our study combines quantitative and qualitative analyses, and includes vocal and visual aspects of speech delivery. The party conference speech calls attention to the institutional ritual of the party conference. Relying on a political version of 'structured informality' (Bradley et al. 2014), it is staged as a dialogue with the audience, so as to foster consensus over the leader's words. As a political genre event, the party conference speech favours political momentum over political analysis and focuses on non-controversial or highly symbolic elements, so as to confirm the party's essential identity, and to share it with the whole country.
\end{abstract}

Keywords: Structured informality, Hybridisation, Party conference speech, Multimodality, Gesture, Corpus-based, Episodes (rhetorical), Moves (rhetorical), Enactment (genre), Ritual (institutional), Co-contextualisation, Antanaclasis, Goffman, Conversationalization, Intimacy at a distance

\section{Introduction}

British party conference speeches are a long-standing institution. Each year, the party leader gives a speech about past and future achievements and challenges in front of an audience made of party members. Despite their obvious role in a party's cohesion and evolution throughout the years, party conference speeches remain under-investigated in the area of political discourse analysis. Studies like Faucher-King's (2005) or Heritage and Greatbatch's (1986) have focused on their significance from the standpoints of anthropology, political sociology, or conversation analysis. Finlayson and Martin (2008) identify party conference speeches as a subgenre of political discourse, while remarking that the study of this dis-

Emilie L'Hôte, Université Paris Diderot, SPC

Camille Debras, Université Paris Ouest Nanterre La Défense 
course form has yet to be undertaken in detail: "British political studies does not have a clear picture of the evolution of the generic form of the British conference speech. That evolving form constitutes a stage upon which a leader is placed" (Finlayson and Martin 2008: 455).

In this chapter, we propose to analyse party conference speeches given by the leaders of the two main British political parties as multimodal genre events (Steen 2011) that aim to provide a privileged platform for dialogue with the British public. Based on a large corpus of recent texts (1994-2013), we analyse the interaction between context, text and code - as defined by Steen (2011) - in our data to refine the definition of that discursive stage. Our study suggests that the party conference speech functions as a political genre event whose main goal is to confirm the party's essential identity, and to share it with the whole country. Party conference speeches rely on the careful selection of the political concepts brought forward; they also construct a political version of 'structured informality' (Bradley et al. 2014) at the code level, and strategically borrow from other genre events, in a way that is consistent with larger societal and discursive evolutions (Garzone and Ilie 2014).

Given the complex nature of our object of study, we agree with Steen's view that multiple points of entry on the data are needed to get a full picture of the phenomena at work. In accordance with his call for a "multifeaturemultidimensional model" (Steen 2011: 37) inspired by existing models (e.g. Biber (1988) for the study of register), we propose a multimodal approach to the genre event of the party conference speech. Our approach combines quantitative and qualitative analyses; it includes visual and vocal aspects of speech delivery, and takes into account the reception of the speeches by the various audiences involved in the event.

We first describe the corpus and methods, as well as the socio-cognitive framework we adopt for our genre analysis. We then show how the party conference speech aims to provide a given party and its leader with a privileged platform for dialogue with the British public. We focus on the different strategies used by the speaker to emphasize that the genre in question is being enacted, before showing how party conference speeches fulfil their political goals at a multimodal level.

\section{Corpus and methods}

\subsection{A corpus-based multimodal analysis of political discourse}

For the purpose of this study, we rely on a 'corpus-based multimodal analysis of political discourse'. This approach to corpus data analysis is a variation on the 
“methodological synergy" advocated by Baker et al. (2008: 274). It is based on the assumption that “'qualitative' findings can be quantified, and that 'quantitative' findings need to be interpreted in the light of existing theories, and lead to their adaptation, or the formulation of new ones" (Baker et al. 2008: 296). Our approach (Debras and L'Hôte 2015) incorporates selected elements of cognitive linguistics (semantic frames, prototype theory, conceptual metaphor theory) and multimodality in the advocated combination between corpus linguistics and CDA. This approach is ideally suited to the study of genre as defined by Steen as "individual action patterns that involve not just language but also, and crucially, cognition and communication" (2011: 28). According to him, when engaging in a genre event, participants have knowledge and expectations about three main variables: (i) the 'code', or linguistic aspects of the event (modality', language, register, style, rhetoric), (ii) the 'text', or cognitive aspects of the event (content and ideas, type, form and structure), and (iii) the 'context', or interactional aspects of the event (participant identities, relations and roles, goals and functions of discourse, setting, norms and values of domains, and medium). Our approach aims to account for the specific genre event of the party conference speech by highlighting the interconnections between these three main variables and by integrating document-oriented and interaction-oriented perspectives (Steen 2011: 30).

We adopt a socio-cognitive approach of genre, in which we argue that the context and the circumstances of production of the speeches are at the basis of the model of the party conference speech as a genre event. Following Goffman (1986), we argue that genre stems from repeated social, historical and cultural frames of experience, which in turn shape our cognitive knowledge, expectations and perceptions of social events. Genre is constituted in those features of experience that remain stable across social events. Based on these features, speaker and audience(s) know what to expect and how to react to the various elements at play. In that respect, genre "provide[s] socio-cultural, psychological, and formal (linguistic or multimodal) orientation as well as order to people in the complex universe of media and communication” (Steen 2011: 22).

The context of a party conference speech must be understood at three different levels. (i) The speech is the main highlight of the larger institutional ritual of the party conference (Mariot 2006, 2009). As such it is limited in time, and it must be powerful. It is not just a textual transcript but also a spoken performance, delivered to various audiences through different media: party members at the conference, national viewers on $\mathrm{TV}$, and worldwide followers on the Internet

1 This word is used in Steen's sense of the term: language vs. other sign systems. 
(Youtube and Twitter ${ }^{2}$ ). In that respect, accounting for a party conference speech is not only about what discourse content is delivered but also how a party leader performs this content in a given place, at a given moment in time. Verbal discourse is combined with non-verbal elements like prosody and gestures, which allow for co-contextualisation in meaning creation (Thibault 2000: 362; Bradley et al. 2014). (ii) The speeches included in our data belong to modern-day versions of the party conference, and as such they have gone through a process of 'hybridisation'. We follow Garzone and Ilie's (2014) analysis of the hybridisation of discourse as the result of the impact of broader developments in society (e.g. a general 'conversationalization' of political speeches in the Western World (Steen 2011: 33)), evolutions in predominant ethical and societal values, attitudes and beliefs (e.g. a tendency for 'political cross-dressing' in Britain), and alterations in discursive practices (e.g. new media becoming a new version of 'intimacy at a distance' (Horton and Wohl 1956)). As such, party conference speeches may borrow from other genres such as the political debate, the catechism, the comedy routine, or the casual conversation. (iii) Each speech is uttered by a given leader at a given moment: at the individual level, the leader himself may have specific issues to address, depending for instance on whether the party is in opposition or in power.

We adapt part of Bateman's definition of a multimodal genre (2008) to connect Steen's three variables. The different layers of context determine the selection of the text and the code necessary to support the genre's recognition (i.e. emphasising evidence that the genre is being enacted). This includes references to the circumstances of production of the speech and the conference ritual itself. The speaker achieves this fin goul by creating an atmosphere of 'structured informality' (Bradley et al. 2014), which emphasizes the fundamentally dialogical dimension of the speeches (Feldman and Bull 2012). As evidenced by Bradley et al. (2014), structured informality occurs when different multimodal strategies are used in alternation: at times, the speaker asserts the genre's expected authority dynamics (e.g. teacher-student, leader-party member), while at others he mitigates the hierarchical distance between speaker and audience. The speaker also uses multimodal resources to anticipate, trigger (Heritage and Greatbatch 1986) or respond to the audience's reactions. Context also determines the main text of the speech, i.e. the main ideas communicated to the audience. In party conference speeches, this text usually aims to place the party on a privileged stage and to share its main identity by emphasising non-controversial elements of the party's policy choices and by bringing the quintessence of the

2 In the next steps of our project, we plan an analysis of the tweets issued by the two main parties' press offices during the speeches, to develop the multimodal aspect of our analysis. 
party's brand to the foreground. A speaker may create an image of unity for the party by pre-empting dissent and neutralising opponents, by staging fictional dialogues with them, or by giving the audience no-alternative choices. This text, in turn, selects specific code and co-contextualises the essence of the party with specific pragmatic strategies (e.g. gestures). Other pragmatic strategies include 'episodes' (Bradley et al. 2014) and 'moves' (Bhatia 2014) as part of the speeches' text.

The rest of this section details essential elements of our multimodal approach: the corpus data, the use of WMatrix for quantitative analyses, and the gesture coding grid used to analyse Tony Blair's 2006 party conference speech.

\subsection{Corpus description}

A preliminary corpus of political speeches was compiled for the study of the leader's speeches at the party conference as a political genre event. It is composed of 4 subcorpora - all dating from 1994 to 2013 (see Table 1 below). The first one is a compilation of the Labour leaders' speeches at the party conference (henceforth LPCS for Labour Party Conference Speeches). The second Labour subcorpus is a compilation of non party conference speeches delivered by the leader of the party for the same time period (henceforth LnPCS for Labour Non Party Conference Speeches). A parallel set of subcorpora was compiled for the Conservative party (TPCS for Tory Party Conference Speeches, and TnPCS for Tory Non Party Conference Speeches). For the purpose of genre comparisons that go beyond traditional divisions on the British political spectrum, all party conference speeches were compiled into the corpus sections called PCS, and their non party conference counterpart is nPCS. As a preliminary compilation of 114 texts and 457,633 words, this corpus is large enough to test the statistic significance of our initial hypotheses and identify the relevant discourse patterns that we detail further in the qualitative part of our analysis.

Table 1: Corpus data description

\begin{tabular}{lllll}
\hline & LPCS & TPCS & LnPCS & TnPCS \\
\hline Words & 119,805 & 107,245 & 144,786 & 85,791 \\
Speeches & 20 & 20 & 46 & 28 \\
\hline & PCS & & nPCS & \\
\hline Words & 227,050 & & 230,577 & \\
Speeches & 40 & & 74 & \\
TOTAL Words & 457,627 & & & \\
TOTAL Speeches & 114 & & & \\
\hline
\end{tabular}


This chapter accounts for multimodal elements (gesture, speech organisation) based on the detailed analysis of the text and video recording of Blair's 2006 party conference speech. It is 56 minutes and 23 seconds long, and is composed of 5227 words. This was his last party conference speech as leader, as he resigned from his positions as Labour leader and as Prime Minister one year later, leaving Gordon Brown in charge. In it, Blair builds an ethos of sincerity; he relies on past experience to give the audience and the party advice for the future; he reminds them of the identity he contributed in building before leaving.

As the qualitative multimodal part of our study focuses on one of Blair's speeches, it highlights elements that are more specific of new Labour discourse, as one representative example of party conference speeches as a political genre event.

\subsection{WMatrix and statistics}

WMatrix is an online tool for corpus analysis and corpus comparison that produces concordance tables, frequency lists, collocation tables and keyness analyses (Rayson 2003, 2009) ${ }^{3}$. The data is tagged for Parts of Speech (PoS) using CLAWS $^{4}$ (Rayson 2003: 64-66). Semantic annotation for semantic concepts is performed using USAS 5 .

WMatrix's keyness analysis is a comparison between two frequency lists using log likelihood ratio as a statistical test (Meyer 2002: 126). One of WMatrix's strong points is that keyword analysis can be extended to analyses of key grammatical categories (or Parts of Speech) and key semantic concepts thanks to the available taggers (see below). Each word/semantic tag/POS tag in the primary corpus is compared to its equivalent in a secondary corpus. The software then evaluates whether the difference between the frequencies in the two corpora is statistically significant or not ${ }^{6}$, and finally reorders the word/tag list according

3 For detailed descriptions and a discussion of concordance tables, concordance analysis and collocations, see Sinclair (1991), Baker (2006: 92-3), and Archer (2009). For a detailed discussion of frequency lists, see Rayson (2008).

4 Constituent Likelihood Automatic Word-tagging System.

5 UCREL Semantic Analysis System.

6 It is hard to find any kind of popular consensus about cut-off points in the literature (Baker 2004: 351). We have chosen to move from a standard cut-off point at $p=0.01$ to results yielding a p-value inferior to 0.0001 , which means an LL score equal or superior to 15.13 . This choice was influenced by the generally skewed nature of corpus data (Oakes 1998: 4) and the fact that multiple comparisons are often carried out on the same data set: according to Kessler (2001: 44), for instance, a higher significance value is needed when multiple comparisons are taking place, on the grounds that there would otherwise be too strong a risk to mark as significant a result actually due to chance. 
to the statistical score obtained. WMatrix identifies both positive keywords (words that are over-represented in the primary corpus), and negative keywords (words that are under-represented in the primary corpus). '+' signs are displayed next to positive keywords in the table, and '-' signs indicate negative keywords.

\subsection{Multimodal analysis of Blair's 2006 speech}

Our analysis of Blair's 2006 party conference speech is multimodal. It includes a detailed analysis of the script of the speech, based on a pragmatic study of the 'episodes' and rhetorical 'moves' at play in the speech. These elements are then combined with a study of the non-verbal dimensions of the spoken performance.

The script of the speech was annotated in Esct. We adapt Bradley et al. (2014)'s definition of 'episodes' as rhetorical speech units consisting of a main point the leader wishes to communicate to his audience(s). These are then divided into episode stages, which mobilize a repertoire of multimodal meaning-making resources. We argue that these stages are similar in meaning and function to what Bhatia (2014: 10) has termed 'rhetorical moves', i.e. "the socio-cognitive patterns that most members of a professional community use to construct and interpret discourses specific to their professional cultures”. We find that Blair's speech relies on a limited number of 'moves' for each 'episode': they may not all appear in each episode, and their order may vary when they do, but they give an exhaustive account of Blair's speech. The full lists of episodes and of rhetorical moves found in the speech are given in Table 2 and Table 3 below. They are referred to throughout our analysis of party conference speeches as a political genre event in the next section.

Table 2: Episodes in Blair's 2006 party conference speech

\begin{tabular}{ll}
\hline & Episodes \\
\hline 1 & Prologue: giving thanks \\
2 & Government achievements at national and international level \\
3 & Leadership achievements at party level \\
4 & Personal announcement 1: Stepping down \\
5 & Global issues \\
6 & Public services \\
7 & Crime \\
8 & Terrorism \\
9 & Personal announcement 2: Veiled justification of war in Iraq \\
10 & Role of Britain in the world \\
11 & The Conservatives \\
12 & Call to battle \\
13 & Closing \\
\hline
\end{tabular}


Table 3: Rhetorical moves in Blair's 2006 party conference speech

\begin{tabular}{l} 
Rhetorical moves \\
Thanking Contextualisation of issue \\
Philosophy/advice of leader \\
Anecdote/Humour/irony \\
Labour's achievements/future plans \\
No alternative choice (L'Hôte 2014) \\
Dismissal/reframing of dissent \\
\hline
\end{tabular}

The vocal features of Blair's speech are analysed in PRAAT (Boersma and Weenink 2015), and its visual components are annotated in ELAN (Wittenburg et al. 2006). Although several body articulators can serve conventional linguistic functions (e.g. facial variations like eyebrow movements), we focus on the most visible visual strategies here, i.e. the forms and functions of observable head and hand gestures with respect to speech. There is no absolute categorization for gesture functions; gestures can also be multifunctional (Kendon 2004). Our annotation template relies on functions identified in two major gesture typologies (McNeill 2005: 38-41; Kendon 2004: 158-159). It is composed of the following tiers:

(i) head movements: head nod, head shake, head tilt to the side, other;

(ii) hand gesture forms: precision grip, index pointing up, both palms straight facing each other, open palm(s) lateral, other;

(iii) hand gesture functions: referential, abstract referential (metaphoric), deictic, pragmatic, beat;

(iv) audience reaction: laughter, applause, other.

Using online material for multimodal analysis has advantages and drawbacks. When the video is available online, it can be downloaded in the chosen format. Yet most political speeches are already edited for media broadcasting: the camera often zooms in to get a medium close-up of the politician, leaving out a large part of the speaker's gesture space. The multiple cameras used to record the speech also regularly focus on audience reaction - either of people mentioned in the speech, or general reactions like applause or laughter. As a consequence, the speaker's prosody remains accessible continuously but his gestures are not always fully visible, because the camera's focus is either too close to the speaker, or away from him. These elements of video editing do not, however, hinder gesture analysis: most of the speaker's hand gestures are ample enough to be seen by the whole audience, thuo nomaining within the camera's angle. 


\section{The party conference speech as a political genre event}

A first look at keyness analyses for party conference speeches vs. non-party conference speeches suggests consistent differences between the two data sets. As shown in Figure 1, Figure 2 and Figure 3 below, the number of significant differences is higher when we compare party conference speeches and non party conference speeches for the same party (Labour (173), Conservatives (161)) than when we compare LPCS with TPCS (107), or LnPCS with TnPCS (115). This confirms L'Hôte's findings (2014): she shows that contrary to what may have been expected, there tend to be more significant differences between two diachronic images of the discourse of a given party than between two synchronic images of the discourses of two different parties.

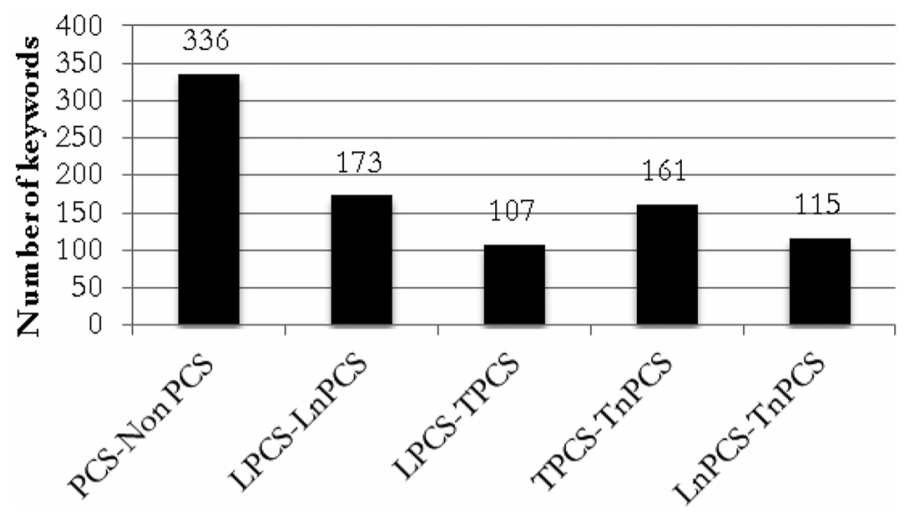

Figure 1: Number of significant keywords for PCS-nonPCS corpus comparisons

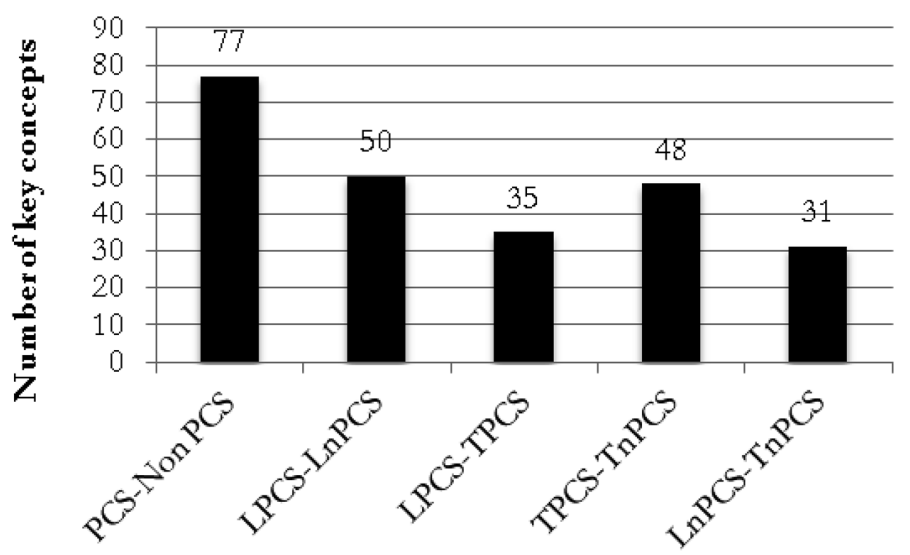

Figure 2: Number of significant key concepts for PCS-nonPCS corpus comparisons 


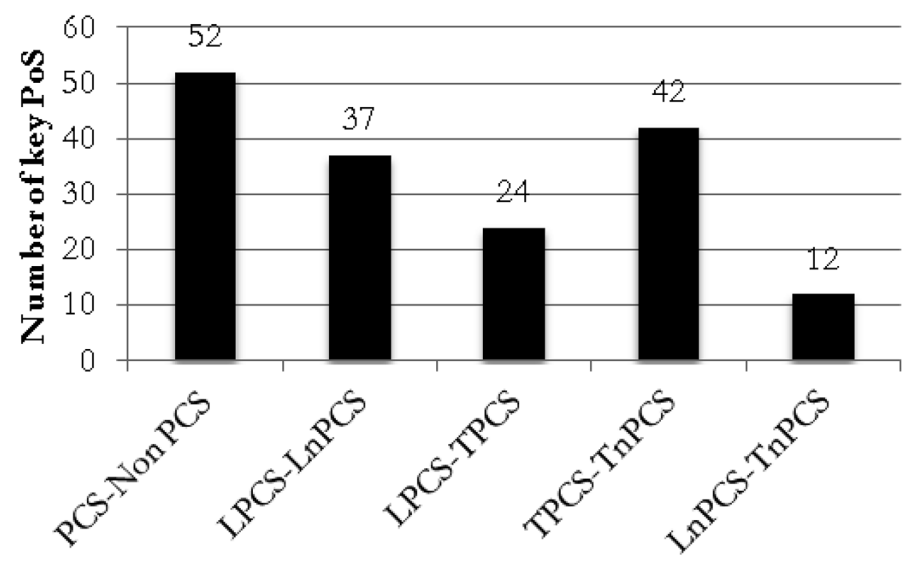

Figure 3: Number of significant key PoS for PCS-nonPCS corpus comparisons

This first insight into our data is detailed in the rest of this section. We start with the comparison between PCS and nPCS in full, before refining the results with concordance lines and collocations analyses, as well as cross comparisons with LPCS-LnPCS, TPCS-TnPCS and LnPCS-TnPCS keyness analyses. These quantitative results are then compared with our qualitative findings based on the multimodal analysis of Blair's 2006 speech. Two main patterns are identified: part of the code selected for party conference speeches serves to signal that a political genre event is being enacted (section 3.1.); the text selected aims at creating a privileged stage for the leader and the party, which in turn leads to the selection of specific code at a multimodal level (section 3.2.).

\section{1 'This is a party conference speech': enacting the genre event}

Keyness analyses reveal various ways in which party conference speeches stage the words of the leader. This meta-discursive dimension is related to the symbolic function of the institution of the party conference. (i) The leader's party conference speech is a speech that calls attention to the institutional ritual of the party conference and its circumstances of production; (ii) it builds an atmosphere of 'structured informality' with the audience(s); (iii) it is staged as a dialogue, not as a debate.

As a specific political genre event, the party conference speech belongs to the wider institutional ritual of the party conference. Our data suggests that the genre of the party conference speech calls attention to its political context: 
it re-emphasizes the role of the participants, and gives a meta-description of what it means to be a party conference speech, as shown in Table 4 below.

Table 4: Enacting the genre event - keyword list $n^{\circ} 1$

\begin{tabular}{lllllll}
\hline Word & PCS (n) & PCS (\%) & nPCS (n) & nPCS(\%) & + +/- & LL PCS-nPCS \\
\hline debate & 33 & 0.01 & 121 & 0.05 & - & 52.11 \\
problems & 62 & 0.03 & 137 & 0.06 & - & 27.83 \\
Mr._President & 26 & 0.01 & 0 & 0 & + & 36.45 \\
conference & 84 & 0.04 & 36 & 0.02 & + & 20.5 \\
week & 90 & 0.04 & 41 & 0.02 & + & 19.55 \\
next_year & 47 & 0.02 & 16 & 0.01 & + & 16.42 \\
bill & 6 & 0 & 32 & 0.01 & - & 19.13 \\
parliamentary & 4 & 0 & 26 & 0.01 & - & 17.69 \\
constitutional & 11 & 0 & 38 & 0.02 & - & 15.33 \\
\hline
\end{tabular}

Party conferences on both sides of the political spectrum last for a week (LL = 19.55, $\mathrm{p}<0.0001$ ), they look forward to the year ahead (next_year: LL $=16.42$, $\mathrm{p}<0.0001$ ), and involve frequent mentions of the President (LL $=36.45, \mathrm{p}<$ 0.0001). The noun conference itself is significantly more frequent in PCS than in nPCS (LL $=20.5, p<0.0001)$, as shown in (1) below:

(1) Honoured and humbled by the trust you have given me, I speak to you for the first time at our conference as prime minister and leader of this party (LPCS).

Gordon Brown opens his 2007 conference speech by focusing on his newfound role in the Labour Party after Tony Blair's resignation (prime minister and leader), and calls attention both to the event itself (our conference) and to the audience (you). His opening mention of honour, humility and trust sets up an interaction based on values, which emphasizes politeness and the audience's positive face (Goffman 1967; Brown and Levinson 1987). Example (2) points to a somewhat similar strategy in Conservative party conference speeches:

(2) Long after the Labour Party has become too snobbish to go almost anywhere in the country, we're coming back to Blackpool. I've enjoyed this Conference tremendously because of your enthusiasm - and because, as ever, I've had the terrific support and companionship of my wife, Ffion (TPCS).

In this case the conference is mentioned for evaluation (enjoyed), and comparison with the opponent. The geographical situation of the conference (Blackpool) 
serves to boost the speaker's popular ethos - as well as the party's, once more in comparison with Labour's alleged snobbishness. After referring to the party and the audience as a collective we, William Hague resituates his role in the personal sphere with the mention of his wife (Ffion). This is another step in the construction of an inclusive ethos, as Ffion is a distinctively Welsh name, and Hague's wife is a recognized Welsh patriot. This allows the speaker to break with the traditional image of the Conservative leader as an upper-class Englishman. In this example as in our overall data, Conservative mentions of the context of the party conference are directly connected to rhetorical strategies of constructing an identity in contrast with their direct opponent. Conversely, Labour references tend to focus on the ritualistic aspect of the conference notably in connexion with the construction of the speaker's ethos. This is confirmed in example (3), which illustrates a vocative use of the noun Conference that is characteristic of Labour discourse only, based on a concordance analysis of our data:

(3) Gordon, Conference, before I begin my speech I would just like to introduce you to someone sitting on the platform (LPCS).

In 1995, Tony Blair addresses all party conference participants (speakers, organisers and audience) as "Conference", thereby creating a distinct impression of unity while calling attention to the specificities of the genre event. This is coherent with other elements identified in the keyness table under analysis. Party conferences can be described as an institutional ritual (Mariot 2006, 2009), since one of their major functions is to unify the three components of the party: public office, grassroots and central office (Mair 1994). The fact that words like bill, parliamentary and constitutional are used less in PCS than in NPCS (see Table 4 above) calls attention to this strategic context parameter. Unity tends to be achieved by toning down parliamentary identity in favour of the central office and the grassroots component of the party. The nouns debate and problems occur significantly less in PCS than in nPCS, thereby stressing the role of the leader's speech as seeking consensus, as opposed to Labour's initial version of the Parliamentary Report? The noun report is not identified as a keyword in any

7 The leader's speech at the Labour Party Conference originally consisted of a written document destined to be critically examined by delegates, which lead to much debate (Minkin 1978: 214). After WW2, Attlee decided to use the report to address the Conference. This practice was abandoned by Gaitskell, but taken up by Wilson. Debate was thus progressively replaced by "prolonged applause", which became the "symbol of leadership pre-eminence" (Minkin 1978: 216), thereby bringing Labour PCSs closer to their Conservative counterparts. 
of our corpus comparisons. This confirms Pettitt's claim (2012) that the reference to the leader's speech as 'Parliamentary Report' in the conference programme is no more than lip service to a part of the ritual that fell into disuse decades earlier.

The leader's speech to the party conference also builds an atmosphere of 'structured informality' (Bradley et al. 2014): the speaker emphasizes his direct relationship with the audiences by shifting in and out of genre expectations in a given rhetorical episode. As evidenced in Table 5, references to $I$ and you and their related determiners and pronouns are significantly more frequent in PCS than in nPCS.

Table 5: Enacting the genre event - keyword list $\mathrm{n}^{\circ} 2$

\begin{tabular}{lclllll}
\hline Word & PCS (n) & PCS (\%) & nPCS (n) & nPCS (\%) & $+/-$ & LL PCS-nPCS \\
\hline i & 2850 & 1.26 & 1611 & 0.7 & + & 368.06 \\
you & 1671 & 0.74 & 824 & 0.36 & + & 306.54 \\
my & 464 & 0.2 & 270 & 0.12 & + & 54.93 \\
people & 1700 & 0.75 & 1382 & 0.6 & + & 37.96 \\
your & 364 & 0.16 & 237 & 0.1 & + & 29.03 \\
mine & 24 & 0.01 & 4 & 0 & + & 16.16 \\
\hline
\end{tabular}

The leader's party conference speech can at times defuse the expected hierarchy between the party leader and his supporters. It aims at presenting him as close to his people, although not quite as one of them, as in (4) and (5):

(4) I know that for some of you, New Labour has been painful and there is no greater pain to be endured in politics than the birth of a new idea, but I believe in it and I want to tell you why (LPCS).

(5) Well I'm glad you came! Shall I tell you what I felt when I first used to come to this conference and I sat down there, where you are at the moment? (TPCS)

In (4), Tony Blair attempts to argue in favour of the renovation of the party (new Labour): he acknowledges dissent and criticism (I know) while reducing it to a small portion of the party (for some of you), before engaging in a conversation with the audience about his view of the issue (I want to tell you). In (5), the Conservative speaker opens his speech with a casual address to the audience, 
borrowing from the Goffmanian frame of the friendly house call (I'm glad you came!). He thus establishes a conversational register at the onset of the speech, focusing on his personal relationship with the audience. The speaker then alternates between $I$ and you, offering an anecdote (shall I tell you), phrased as a rhetorical question that highlights the interactive quality of his speech. Here as well, the construction of his ethos relies on politeness and positive face strategies, as he puts himself in the audience's shoes (I sat down... where you are), creating an impression of equivalence between leader and party members.

These results suggest an interpretation of self-reference in party conference speeches that differs from the one put forward by Pettitt (2012). For him, variations in the frequency of self-reference over time are connected to each leader's personality; while we do not reject his hypothesis entirely, we suggest that looking at self-reference as a means of connecting with the audience in party conference speeches may yield more productive insights into the analysis of political discourse. As Benveniste remarks (1966), there can only be an $I$ in discourse if there is a you, and vice versa. In the case of party conference speeches, repeated selfreference allows the speaker to focus on interpersonal relations in the speech, thereby creating a valuable impression of 'intimacy at a distance' (Horton and Wohl 1956). In this case, code and text of the genre event shed relevant light on the context variable. Horton and Wohl developed the concept of 'intimacy at a distance' as a way to analyse the new interactions created by the rise of mass media like television. For them, television creates an illusion of face-toface interaction with the viewers, who feel like active participants in an exchange (see also: Montgomery 1999). Given that the first TV broadcast of a party conference dates back to 1954, we can wonder whether Labour leaders did away with the original genre event of the written parliamentary report and turned it into a speech around the same time because they saw the potential of these media innovations, or if TV broadcasters saw the potential of party conferences once they were mostly made of speeches. We argue for the first possibility. With the rise of new media and the broadcast of party conference speeches on websites like YouTube, where viewers are able to comment on the videos, the notion of intimacy at a distance takes on a new dimension, which may actually be one of the reasons for a general 'conversationalization' of political speeches in the Western World (Steen 2011: 33).

The pragmatic analysis of Blair's 2006 speech gives more insight into this phenomenon. The 'Prologue' episode is a good example of structured informality in action: Blair opens his speech by giving thanks, which can be seen as 
characteristic of the expected ritual of party conference speeches, as evidenced in Table $6^{8}$ below.

Table 6: Keyness analysis for THANK

\begin{tabular}{lllllll}
\hline Custom semantic concept & PCS (n) & PCS (\%) & nPCS (n) & nPCS (\%) & +/- & LL PCS-nPCS \\
\hline THANK & 97 & 0.04 & 53 & 0.02 & + & 13.79 \\
\hline
\end{tabular}

While the frequency difference for THANK is not identified as statistically significant based on current LL scores (LL $<15.13, \mathrm{p}>0.0001$ ), we hypothesize that a larger corpus would lead to significant results, given the existing frequency difference between PCS and nPCS in this case. This hypothesis is consistent with our qualitative analysis of the episode, in which Blair moves in and out of genre expectations. He starts with a fairly standard opening, in which he directs his gratitude towards the party and its supporters, in (6):

(6) I'd like to start by saying something very simple. Thank you. Thank you to you, our party, our members, our supporters, the people who week in, week out do the work, take the flak but don't often get the credit. Thank you, the Labour party for giving me the extraordinary privilege of leading you these past 12 years.

This move is repeated 5 times in the Prologue episode: Blair goes from the individual (John Prescott, John Burton) and the personal (my family) to the group and the political (the party, the country). In between, he alternates between high ('Philosophy' move) and low ('Humour/anecdote' move) to create an impression of structured informality. In (7), for instance, humour emerges as Blair borrows from the genre of the award ceremony speech:

(7) It's usual after you thank the family, you thank your agent and yes I do want to thank him and through him the wonderful people of Sedgefield.

The adjective usual, as well as the generic use of definite articles in the family and the agent, stress once again that the speaker is enacting the conventions of the political genre event at the time of utterance. Two fairly standard 'thanks'

8 A custom semantic concept was created by combining frequencies for thank, thanks, thank_you, thanking and thanked in PCS and nPCS. Indeed, the semantic concept that WMatrix automatically associates these words to (S1.2.4+: "Polite") is too wide for the purpose of our analysis of a specific rhetorical move, as it includes words like diplomacy or integrity. Additionally, thank_you is treated as a multi-word expression (MWE) by WMatrix's concordancer, but this MWE is not associated with the same semantic concept as the other realisations of the lemma thank in USAS, which skews the results further still in S1.2.4+. 
moves (the family, the wonderful people of Sedgefield) stand out as they are part of an incongruous shift to a more informal genre. Similar move combinations occur at various moments in the episode, and contribute to creating an atmosphere of structured informality in the speech.

Blair's strategy is co-contextualised at the prosodic level. The several 'thank you' utterances present a highly similar pitch contour (see Figure 4). They are isolated from the rest of the speech by pauses, and take the form of a falling tone ending at a pitch level of around $100 \mathrm{~Hz}$, as shown in the two instances (thank you; thank you the Labour party) represented in Figure 4.
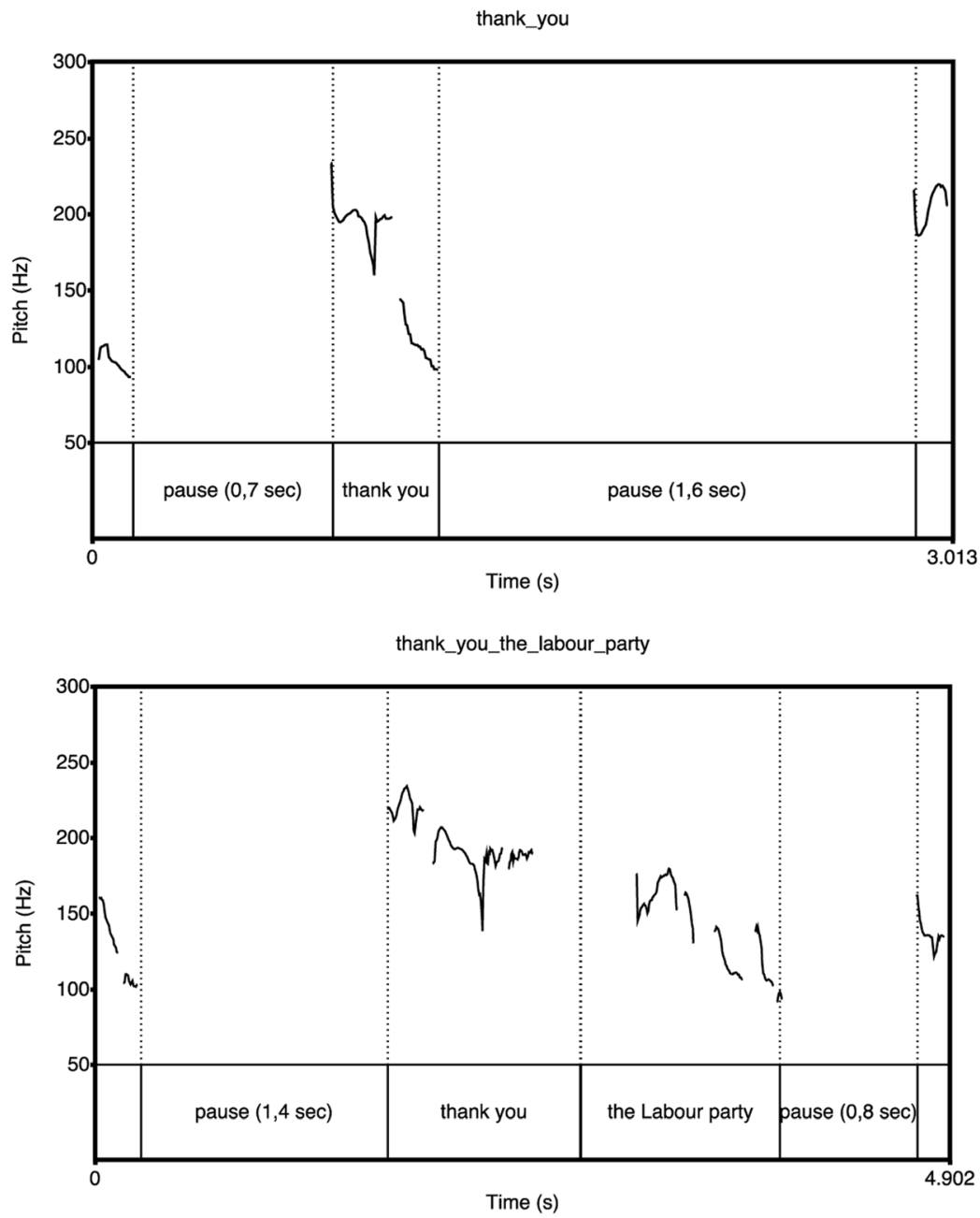

Figure 4: Pitch contours of two 'thank you' utterances in Blair's 2006 speech 
These correspond to the first two occurrences of 'thank you' in the Prologue episode. The pauses that isolate each 'thank you' utterance from the rest of the speech heighten the sense of emotion and solemnity. The repetition of the same vocal form in connection with these 'thank you' utterances makes the specificity of the episode stand out for the listener. The falling tone is often emphasized visually by a synchronized single head nod, in which the head's movement downward becomes iconic of the voice's falling tone (Bolinger 1983).

The dialogic quality of party conference speeches goes beyond structured informality and serves a wider array of strategic purposes. Table 7 points to the high frequency of discourse verbs in the leader's party conference speeches.

Table 7: Enacting the genre event - keyword list $\mathrm{n}^{\circ} 3$

\begin{tabular}{lclclll}
\hline Word & PCS (n) & PCS (\%) & nPCS (n) & nPCS (\%) & + /- & LL PCS-nPCS \\
\hline tell & 234 & 0.1 & 71 & 0.03 & + & 94.35 \\
know & 495 & 0.22 & 247 & 0.11 & + & 88.38 \\
yes & 191 & 0.08 & 60 & 0.03 & + & 73.91 \\
you_know & 66 & 0.03 & 9 & 0 & + & 49.82 \\
said & 292 & 0.13 & 162 & 0.07 & + & 39.78 \\
told & 109 & 0.05 & 37 & 0.02 & + & 38.23 \\
no & 515 & 0.23 & 351 & 0.15 & + & 33.83 \\
say & 412 & 0.18 & 274 & 0.12 & + & 30.12 \\
think & 266 & 0.12 & 166 & 0.07 & + & 24.93 \\
i_believe & 99 & 0.04 & 44 & 0.02 & + & 22.57 \\
look & 47 & 0.02 & 13 & 0.01 & + & 20.99 \\
argued & 2 & 0 & 23 & 0.01 & - & 20.4 \\
claim & 9 & 0 & 36 & 0.02 & - & 16.93 \\
hear & 54 & 0.02 & 20 & 0.01 & + & 16.75 \\
i_say & 71 & 0.03 & 31 & 0.01 & + & 16.74 \\
\hline
\end{tabular}

The speaker can rely on these verbs to strike up a conversation with the audience and with the people of Britain as in (8). He can also use them to create fictitious interlocutors voicing dissent, in order to pre-empt criticism and generate agreement around himself, as in (9).

(8) When I sit in the House of Commons and hear Labour Ministers talking about this or that new piece of regulation I think to myself: it's time they listened to the small businessman I met in Nottingham last month who said to me at this rate, we are going to have one man working in this country and 55 million checking up on him. Britain needs a Common Sense Revolution (TPCS). 
(9) I hear people say we have to stop and debate globalisation. You might as well debate whether autumn should follow summer (LPCS).

Example (8) is a mise en abyme of political anecdotes. The first one stages William Hague at the House of Commons, in the role of a Conservative MP, mentally staging a conversation between Labour Ministers and a small businessman from Nottingham. This conversation within the conversation allows the speaker to present his criticism of Labour's policies in a more concrete way. The conclusion of the story (one man working... and 55 million checking up on him) gives a humorous tone to an otherwise dry economic criticism, and allows the speaker to preserve his political ethos: he is not the initiator of the attack, but he can rely on the fictional businessman's exaggeration to make his point. As the latter is described as a man of the people ( $a$ small businessman), he will not be reproached for a sweeping generalisation that would not have been acceptable of the leader of the Conservative party. In example (9), the indefiniteness of the speaker's interlocutor (people) serves less as the staging of a humorous conversation than as a way to dismiss all attempts at dissent within and outside the party as irrelevant. As the speaker is the only one voicing the criticisms, he necessarily has the last word. Dissent is staged through fictitious dialogue, but is immediately rejected in favour of consensus over the leader's words. This is confirmed by the significantly low frequency of the only two discourse verbs with more negative semantic prosody ${ }^{9}$ (Sinclair 1991) than the others listed in Table 7, namely argued and claim. The aim of the speaker is to stage dialogue, not debate.

The enactment of dialogue leading to party consensus is also achieved with a more positive rhetorical strategy at the multimodal level, as detailed in Table 8 below.

Table 8: Enacting the genre event - keyword list $n^{\circ} 4$

\begin{tabular}{llllllc}
\hline Word & PCS (n) & PCS (\%) & nPCS (n) & nPCS (\%) & $+/-$ & LL PCS-nPCS \\
\hline we & 5177 & 2.28 & 4025 & 1.75 & + & 162.91 \\
our & 2473 & 1.09 & 1940 & 0.84 & + & 73.02 \\
they & 1723 & 0.76 & 1311 & 0.57 & + & 62.66 \\
us & 704 & 0.31 & 546 & 0.24 & + & 22.54 \\
\hline
\end{tabular}

9 Semantic prosody is defined as the "consistent aura of meaning with which a form is imbued by its collocates” (Louw 1993: 157; See also Sinclair 1991). 
The pronouns we, us and they, as well as the possessive our, are all significantly more frequent in party conference speeches than in other speeches. As illustrated in (10), these words create a sense of community among the audience(s):

(10) Labour have stood in the way of everything we've done. Where were they when we cut inflation? When we faced down union power? (TPCS)

In this case, the speaker aims at fostering unity in the audience by opposing we (i.e. the Conservatives) and they (Labour). Relevant collocates for the pronoun we in PCS (see Table 9 below) suggest that the reliance on the first person plura goes further that a 'we vs. them' strategy. The pronoun we can found to refer to the party, the government and the nation, as well as create a more diffuse feeling of belonging and unity (together, all).

Table 9: Selected significant collocates for we in PCS

\begin{tabular}{lll}
\hline LL score & Word 1 & Word 2 \\
\hline 40.94 & We & all \\
37.88 & We & party \\
36.53 & We & nation \\
27.18 & We & Party \\
18.79 & We & together \\
17.23 & We & public \\
15.91 & We & govern \\
\hline
\end{tabular}

In Blair's 2006 speech, references to we or us are repeatedly combined with a specific gesture, in which the speaker's arm is extended to the side with a slightly curved open palm and extended fingers. This gesture can be performed with one hand only; the use of both hands indicates extra emphasis (Müller 2004). In examples (11) (illustrated in Figure 5) and (12) (illustrated in Figure 6), Blair uses both hands to perform the gesture.

(11) If we want our values to be the ones that govern global change, we have to show that they are fair, just and delivered with an even hand.

(12) The danger, for us as a party, is not ditching New Labour. 


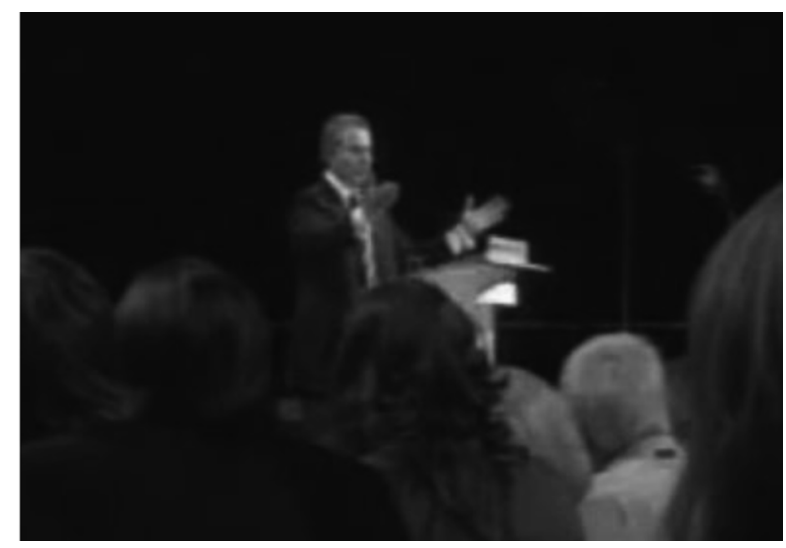

Figure 5: Blair's cron we "we" in "if we want our values to be the ones that govern global change"

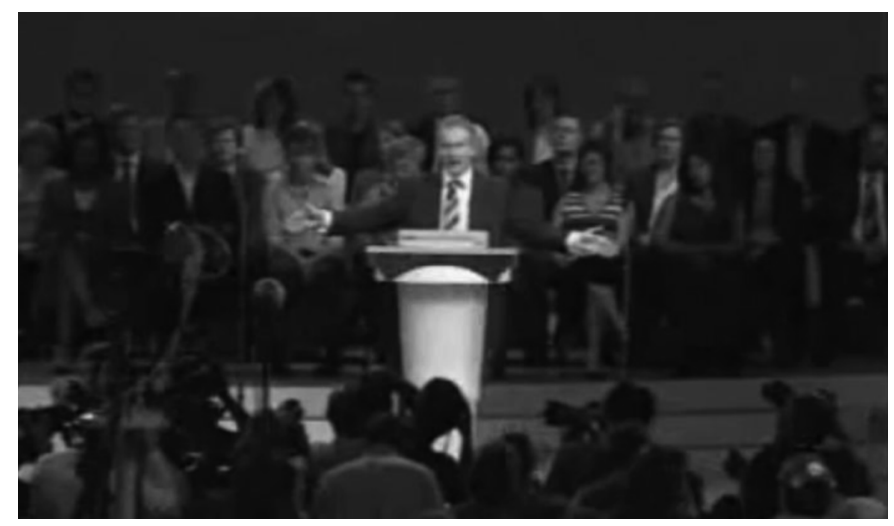

Figure 6: Blair's cpon

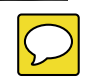

Because of their schematic nature (Cienki 2005), gestures are often multifunctional (Kendon 2004). Blair's lateral open palm gesture is no exception, lending itself to various yet connected interpretations. In combination with we (in (11)), Blair's open palms can be understood as a representational gesture of inclusion: he embraces the audience with his whole body. When the same gesture accompanies for us as party (in (12)), this concrete meaning drifts towards an abstract reference, and can be interpreted as a metaphorical gesture (Cienki 2008) representing the party's unity. The power of the gesture actually lies in blurring the line between concrete and abstract: it could refer to both at once, designating the audience as a metonymic representation of the party's unity, 
just as a mention of the pronoun we may metonymically refer to the audience, the party and the nation simultaneously.

The lateral open palm gesture is not necessarily used in combination with a reference to the audience or to the party. In many other instances, it is not connected to any specific referent, and rather serves to present the audience with a new idea (see Figure 7).
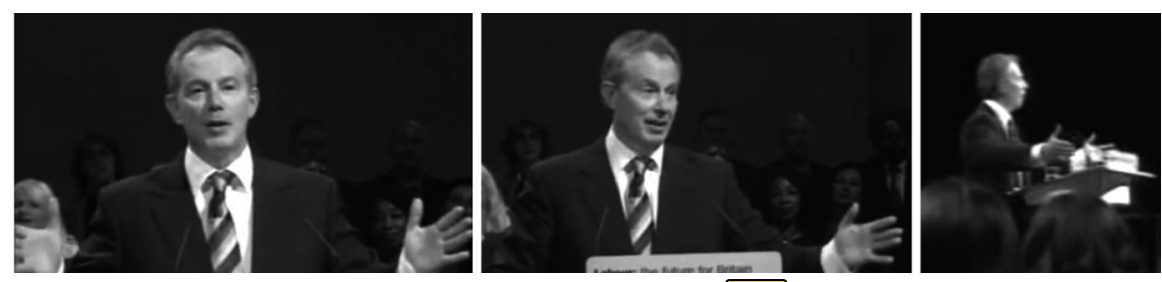

Figure 7: Examples of Blair's cman lntamal nalms gesture

In these cases, the gesture can be described as pragmatic (Streeck 1994, 2009): the speaker uses an open palm to present his interlocutor with something abstract (a new idea), as if it were a concrete object placed in his hand (Müller 2004). Gestures like this one, which refer to the interpersonal relation with the interlocutor, have been described as 'interactive' (Bavelas et al. 1995). Interactive gestures are usually performed with a horizontal open palm facing upwards, when they present a new idea in conversation. Blair's gesture can be analysed as a variation on this upward palm gesture: his lateral open palm(s) take(s) into account the whole audience as interlocutor. Its main goal is to represent the audience, or to refer to them explicitly as interlocutor. The different functions of this gesture are united by its meta-pragmatic (Streeck 2009) dimension: every time this gesture is used, it lays emphasis on the speech as being enacted here and now. We have seen that the party conference speech is a genre that enacts its circumstances of production: Blair's lateral open palm(s) gesture shows that this meta-discursive specificity is also performed thanks to visual resources.

This section has shown how context determines a selection of code elements that in turn provide evidence that the genre event of the party conference speech is being enacted. The leader's speech characteristically refers to its circumstances of production and to the wider institutional ritual of the party conference. The party conference speech builds an atmosphere of structured informality with the audience(s) through a series of rhetorical strategies and specific moves. It emphasizes the fundamentally dialogical dimension of political speeches (Feldman and Bull 2012) in order to fulfil a series of strategic and political goals. 
An image of unity and consensus is created by rejecting debate and by highlighting the different levels of community involved in the event.

\section{2 'Talking politics': Fulfilling strategic goals from context to text, to code}

One of the main goals of the leader in a party conference speech is to place the party - and himself - on a privileged stage, and to share the party's common identity. Because of this communicative goal, party conference speeches in our data deal more with image and symbol than with the detail of party policy. These speeches (i) favour political energy over political analysis; (ii) emphasise elements of the party's policy choices that are either highly symbolic and/or non-controversial; (iii) bring the party's values and the quintessence of the party's brand to the foreground.

Party conference speeches focus on gathering political momentum rather than on political analysis. This strategy explains apparent contradictions at the code level, as exemplified in Table 10, which concentrates on Labour discourse.

Table 10: Talking politics - keyness analysis $n^{\circ} 1$

\begin{tabular}{clllllll}
\hline Concept tag & LPCS (n) & LPCS (\%) & LnPCS (n) & LnPCS (\%) & $+/-$ & LL & Concept name \\
\hline 127 & 0.11 & 281 & 0.19 & - & 34.08 & Confident \\
78 & 0.07 & 36 & 0.02 & + & 24.82 & Bravery \\
\hline
\end{tabular}

The semantic concept E6+ (Confident) is identified as significantly less frequent in LPCS than in LnPCS, while the concept E5+ (Bravery) is used significantly more. E6+ includes words like faith, confident and trust, while E5+ includes words like courage, heroic and brave. These two semantic concepts are fairly close in terms of text, i.e. the meanings and the ideas they convey, so that out of context, such differences in frequency may seem contradictory. But these differences take on new coherence when they are analysed through the prism of the party conference speech as a political genre event. They indicate that the goal of the speaker is not to make epistemic judgments about the chances of success of a given policy for instance (Confident), but to build on the raw political energy his speech is generating among the audience(s) to get political momentum for the coming year (Bravery). Blair's 2006 speech suggests that gesture serves as a co-contextualising strategy in this case, specifically with the recurrent use of the index pointed upwards. As illustrated in Figure 8 below, this gesture is 
performed in various forms during the speech: with the left hand or right hand and with onc hand on two for extra emphasis (Müller 2004).
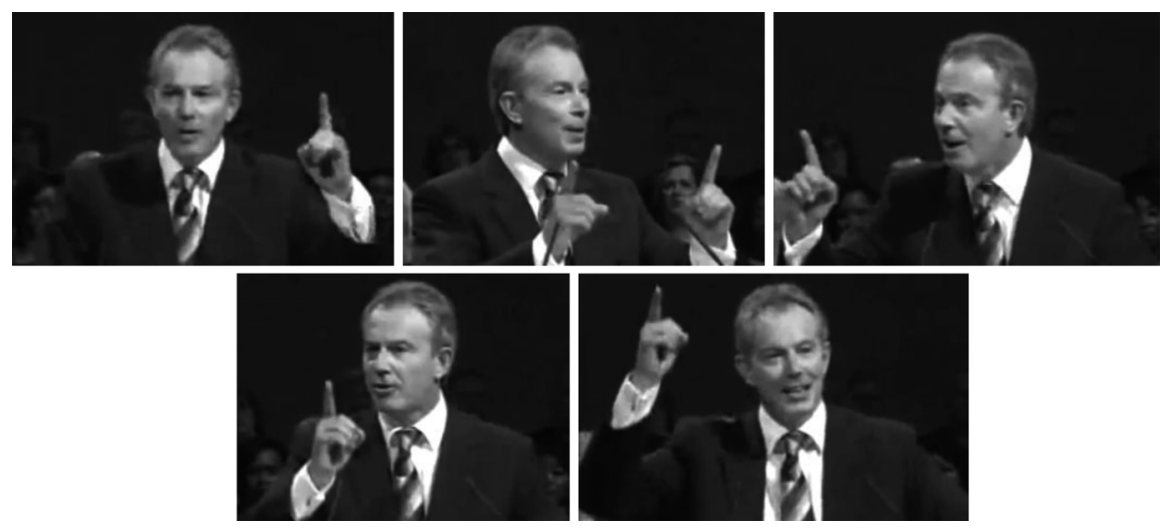

Figure 8: Instances of Blair's index pointed upwards

Throughout the speech, Blair uses this gesture to emphasize a specific element of the speech by directing the audience's attention to it. It is never used to represent something concrete (e.g. an object located above). Rather, it is linked to the content of the speech in a more abstract, metaphoric way (Cienki 2008). Because of the indeterminacy and the schematicity of gestures (Cienki 2005), no exact metaphoric mapping can be identified with certainty for this gesture, which seems to conflate GOOD IS UP, STRENGTH IS UP and POWER IS UP. This gesture consistently indicates high specificity and high importance for the topic discussed, as well as high power as far as the speaker's discursive ethos is concerned (Bradley et al. 2014).

Blair's upward-pointing index is also a means for him to enhance the interpersonal dimension of his speech and hence tighten the bond with the audience while simultaneously reasserting his position as leader: this is 'structured informality' in action. In several cases, Blair associates the upward index with the use of imperatives, giving firm advice to the live audience of the speech. He can thus highlight the interactional dimension of the context of the speech delivery by including the audience members as participants, and simultaneously reinforce his authority in this asymmetrical relation with the audience: he is the one speaking and giving advice. At 9'50, Blair reminds his audience that Labour should not yield to the Conservatives' criticisms, before concluding:

(13) Don't lose heart from that, take heart from it! 
The exclamation in (13) uses a continuously rising voice pitch, which invites a reaction from the addressee (Morel and Danon-Boileau 1998). The invitation is successful, as it is welcomed by a 4-second round of applause. The three prosodic stresses are visually enhanced by beats performed with the index finger pointed upwards (see Figure 9 below).

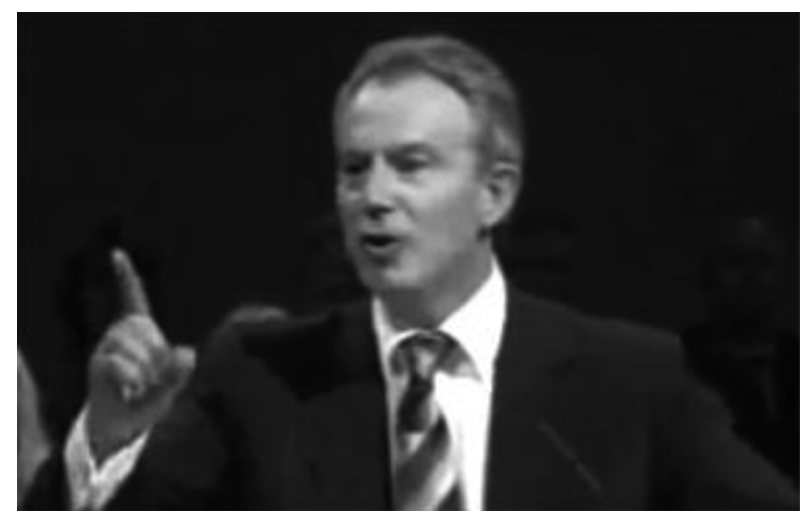

Figure 9: Blair’s right index pointed upwards on “Don’t lose heart” ((13))

The multimodal combination of the imperative form with a conclusive rising voice pitch, as well as the beat gestures, make Blair sound like a charismatic leader galvanizing his troops before the fight. The point is not to make projections about figures and the success of politics, but to build up raw political energy for the year to come.

Given their main communicational goal, party conference speeches also favour text that has strong symbolic value for the public - or that is directly connected to the identity of the party. Non party conference speeches, on the other hand, rely more frequently on technical, specific terms to talk about similar policies (see Table 11 below).

Table 11: Talking politics - keyness analysis $n^{\circ} 2$

\begin{tabular}{lclclcl}
\hline Word & PCS (n) & PCS (\%) & nPCS (n) & nPCS (\%) & +/- & LL PCS-nPCS \\
\hline NHS & 259 & 0.11 & 86 & 0.04 & + & 93.5 \\
taxes & 136 & 0.06 & 37 & 0.02 & + & 61.78 \\
social_security & 5 & 0 & 46 & 0.02 & - & 37.35 \\
economic & 128 & 0.06 & 246 & 0.11 & - & 36.08 \\
job & 165 & 0.07 & 95 & 0.04 & + & 20.18 \\
\hline
\end{tabular}

The adjective economic is significantly less frequent in PCS than in NPCS (LL = $36.08(-), \mathrm{p}<0.0001)$, while taxes and job are identified as positive keywords. 
Similarly, while social_security occurs significantly less in PCS than in nPCS, we get opposite results for NHS. Once again, these apparent contradictions at the code level gain new coherence in light of the text and the context of the speech. The NHS has strong symbolic value in Britain overall - and in the Labour party in particular, as in (14):

(14) The NHS was the greatest achievement of the post-war Labour government. It was based on a single, clear, enduring value: that healthcare should be based on need not ability to pay (LPCS).

Reference to the post-war Labour government strengthens the ethos of the speaker by connecting him with his uncontroversial political predecessors. The symbolic weight of the phrase is clearly stressed with a mention of value. Social security, on the other hand, is a concept defined in the Universal Declaration of Human Rights, which metonymically refers to the entire national insurance system in the UK. The few instances of the phrase in PCS also indicate that it tends to be used in more negatively connoted arguments, as in (15):

(15) [T]hat was the greatest part of the Great Labour Lie. Social security bills have soared. Dependency has increased (TPCS).

Social security is used as a modifier for the noun bills, and associated with the verb soar, which is characterised by negative prosody when used in its metaphorical meaning of "rapid increase above the usual level" (OAD 2009). A similar argument goes for the distinction between taxes and job (specific, symbolic) vs. economic (generic). The goal of the speaker - as the leader of the party - is to address the audience's core political values and to capitalise on their attachment to political symbols, rather than to proceed with a demonstration that is either too generic or too technical ${ }^{10}$. Thus, while party conference speeches bear some similarities with the genre event of the campaign speech or the election manifesto - with the prominence of words like win or fight (see Table 12 below), they stand apart because of their weak reliance on a technical frame to talk about politics.

10 See http://fm.cnbc.com/applications/cnbc.com/resources/editorialfiles/2013/09/26/FI10863crelease\%209-25-13.pdf (accessed 24/07/2014) for similar results in a CNBC poll on US public opinion regarding health care reform, which differs significantly depending on whether the same bill is called Obamacare or the Affordable Care Act. 
Table 12: Talking politics - keyness analysis $n^{\circ} 3$

\begin{tabular}{lllllll}
\hline Word & PCS (n) & PCS (\%) & nPCS (n) & nPCS (\%) & + /- & LL PCS-nPCS \\
\hline & 126 & 0.06 & 49 & 0.02 & + & 36.27 \\
election & 137 & 0.06 & 60 & 0.03 & + & 32.11 \\
govern & 132 & 0.06 & 57 & 0.02 & + & 31.76 \\
\hline
\end{tabular}

In Aristotle's terms (Aristotle 350AD), the function of party conference speeches as a genre event is more epideictic than deliberative. The general frame built by the speaker is value-oriented, not technical. These findings confirm Lakoff's claim that people vote according to their values more than they vote for specific policies and rational arguments (Lakoff 2002).

As shown in Table 13 below, party conference speeches aim to present the audience(s) with a concentrate of the party's values, and the party's brand identity.

Table 13: Talking politics - keyness analysis $n^{\circ} 1$

\begin{tabular}{lclllll}
\hline Word & PCS (n) & PCS (\%) & nPCS (n) & nPCS (\%) & $+/-$ & LL PCS-nPCS \\
\hline party & 533 & 0.23 & 177 & 0.08 & + & 192.39 \\
political & 126 & 0.06 & 276 & 0.12 & - & 55.06 \\
& 28 & 0.01 & 106 & 0.05 & - & 47.2 \\
generation & 150 & 0.07 & 61 & 0.03 & + & 40.13 \\
organisations & 5 & 0 & 47 & 0.02 & - & 38.52 \\
tough & 140 & 0.06 & 56 & 0.02 & + & 38.5 \\
common_sense & 65 & 0.03 & 18 & 0.01 & + & 28.99 \\
choice & 174 & 0.08 & 91 & 0.04 & + & 27.73 \\
instincts & 27 & 0.01 & 3 & 0 & + & 22.46 \\
journey & 36 & 0.02 & 7 & 0 & + & 21.85 \\
stand_for & 41 & 0.02 & 12 & 0.01 & + & 17.22 \\
\hline
\end{tabular}

Words like party and instincts are significantly more frequent in PCS, whereas words like political and organisations occur significantly less than in nPCS. The function of the leader's party conference speech as a genre event is thus less to discuss the role ( $\mathrm{LL}=47.2(-), \mathrm{p}<0.0001$ ) that the party is meant to play on the national scene, than to determine what the party and its leader are meant to stand for $(\mathrm{LL}=17.22(+), \mathrm{p}<0.0001)$. The speaker is expected to address issues of image and ethos, as in (16): 
(16) I believe in enterprise. I believe in education. I believe in self-reliance. [...] I believe in the nation. So let's hold our heads high and say to New Labour and the whole world: these are the things we believe in, these are the values from which we will never retreat. Let's say to the world, this is what we believe in and this is what we will always stand for. Let's challenge New Labour [...] This is what is sacred to us - when will anything be sacred to you? (TPCS)

Values are mentioned several times in the example, especially in connexion with an attack on the Conservatives' opponent (Let's challenge New Labour). The repetition of the verb believe and the adjective sacred, in combination with a series of questions asked to their fictional Labour interlocutor borrows from the genre event of the catechism, which is used to emphasize the prominence of the passage in the body of the speech.

Table 13 also indicates that party conference speeches emphasize a given party's brand in the eyes of the audience. A series of keywords pointing to essential elements in the parties' identities (see also: L'Hôte and Lemmens 2009; L'Hôte 2010, 2014) occur significantly more often in PCS than in nPCS. The noun generation points to Ed Milliband's new rallying call of Labour's 'New Generation'; the multi-word expression common_sense appears mainly in David Cameron's 2010 speech, in which he defines the Conservatives' 'Common Sense Revolution' (see also: Debras and L'Hôte 2015). The noun journey is also identified as characteristic of party conference speeches ( $L L=21.85, p<0.0001$ ). It is connected to new Labour's narrative of change and modernisation, which played a major role in the discourse of the party from Blair's start as leader in 1994 to the 2010 elections: in new Labour discourse, POLITICS IS A JOURNEY is a recurrent metaphor. The adjective tough ( $\mathrm{LL}=38.5, \mathrm{p}<0.0001$ ) points to Labour's partial adoption of a Strict-Father model of politics (Lakoff 2002) during Blair's leadership, as in the famous slogan: "tough on crime, tough on the causes of crime". This formula initiated an era of 'rhetorical cross-dressing' in British political discourse, in which the lines between Lakoff's two initial models are increasingly blurred (see also: L'Hôte 2014, Debras and L'Hôte 2015).

The keyword choice belongs to both parties' brands, because it can have two distinct interpretations at the text level. The noun choice can be defined as "a range of possibilities from which one or more may be selected" (OAD 2009). The concept associated with this definition belongs to the general economic and political philosophy of the Conservatives. According to them, the individual should be able to make decisions for themselves and not let the government interfere, as in (17): 
(17) [A]t Blackpool, Labour filched two of the principles on which we fought the last general election: opportunity and responsibility. But wasn't it interesting that they left out two others: personal choice and private ownership. They're vital to us (TPCS).

In this quote, the speaker addresses the circulation of political philosophies across the political spectrum, in a distinctly conversational tone (filched, wasn't it interesting); once again, he mixes high and low registers for an atmosphere of structured informality. He acknowledges a certain degree of discursive 'crossdressing' with Labour, which is framed as political plagiarism on the part of their opponent (filched). The rejection of a potential equivalence between the two parties is taken further with the concept of choice: the noun phrase personal choice is defined as one of the essential principles that define the Conservative philosophy, and directly associated with private ownership as the elements that distinguish the party from its direct opponent. This connexion is emphasized by the alliteration in " $p$ " and the equivalent structure between the code expressing the two concepts $(\mathrm{Adj}+\mathrm{N})$. The modifier personal stresses that the noun must be understood as referring to its initial definition, i.e. an individual's decision. A relevant code element on the part of Conservative leaders in modern-day Britain, choice has also been taken over by their main opponent, who uses it in a different sense. With choice, Labour profiles the act of decision-making itself instead of the range of available possibilities (OAD 2009). This use of the word relies on what L'Hôte (2010) has termed 'no-alternative choice', in line with Mouffe's thesis of the emergence of a politics without adversary in contemporary Britain (1998). It is illustrated in (18):

(18) I say this to Sinn Fein and, after events of the last 24 hours, to Loyalist groups as well. You have your chance to take the path of peace. It is your duty to take it as members of the human race. Honour it and you shall play your part. Fail in that duty and I swear to you, the search for justice and reconciliation will carry on without you. The choice is yours (LPCS).

In this example, choice is used in its no-alternative sense: the possibilities at hand are framed in such a way that only one of them is acceptable. Even if the speaker presents several alternatives, the choice has already been made for the addressees (take the path of peace and be members of the human race vs. be left out of the decision-making process). Example (18) also indicates that no-alternative choice is often a thinly veiled threat on the part of the speaker. In this instance, he stages a direct exchange with Sinn Fein and Loyalist groups 
(I say) and relies on structures akin to imperative and-conditionals (Sweetser and Dancygier 2005; Sweetser 1990) (Honour it and... / Fail in that duty and...). Described in terms of mental spaces, the latter include "a suggestion to do P, followed by an assertion that in the space where P happens, Q will hold" (Sweetser and Dancygier 2005: 243). While the functions of 'and-conditionals' range from positive suggestions to threats and deterrents, the meaning implied by the speaker remains the same: "[m]ake the right choice and I'll see you through any trouble that may ensue" (Sweetser and Dancygier 2005: 242). This analysis also suggests that the concept of 'no-alternative choice' in new Labour discourse goes far beyond occurrences of the noun choice at the code level, to include constructions such as 'or-' or 'and-conditionals' (see also: L'Hôte 2014).

A multimodal perspective on Blair's 2006 speech shows that a given element of a party's brand identity, like 'no-alternative choice', is not only realised in the script of the speech. It is also one of the main rhetorical moves that the speaker uses to build the episodes of his speech. This move is often supported by a combination of relevant gestures, as in (19), where Blair defines the values Labour needs, and rejects old-fashioned values. He provides the audience with an argument that had become a key one for new Labour discourse by 2006, i.e. going back to pre-1994 Labour is impossible.

(19) Values unrelated to modern reality are not just electorally hopeless, the values themselves become devalued, they have no purchase on the real world.

This example is identified as part of a 'no-alternative choice' rhetorical move in which Blair initiates a negative characterisation of the rejected possibility (go back to pre-1994 Labour). It does not display any of the lexical or constructional cues for no-alternative choice identified above. Instead, Blair relies on a discursive strategy known as 'antanaclasis', or the association of multiple meanings of the same word (or idea) - some literal, some metaphorical - in a single statement. At several other moments in the speech, antanaclasis allows Blair to transition smoothly from concrete achievements to issues of party identity and party branding. When gesture accompanies antanaclasis, it takes on a metapragmatic function (Streeck 2009), pointing to the way verbal discourse is used for interpersonal impact. In (19), Blair relies on a multimodal version of antanaclasis to strengthen a political threat that remains veiled at the level of the script. Gesture selection aims to make a veiled threat more obvious to the audience(s) of the speech. Blair shifts from the abstract (values) to the concrete (devalued, no purchase), and from the theoretical to the metaphorical to initiate 
his rhetorical move. Devalued and no purchase are realisations of the conceptual metaphor SYMBOLIC VALUE IS MONETARY VALUE. Given the negative semantic prosody (see ft 13) of the basic sense of devaluation, and the reliance on actual negation in the case of no purchase, the image can easily be interpreted as a threat regarding negative consequences in case Blair's advice should not be followed after his resignation. In (19), the pivotal segment the values themselves become devalued is highlighted by two specific gestures performed with both hands on the prosodic stresses of values and devalued. On values, Blair makes a pragmatic gesture where his two palms are facing each other, as if holding a big, round-shaped object (unfortunately only the tip of the left thumb is visible on the video, as illustrated in Figure 10 below). This gesture can be interpreted as an instance of the CONDUIT METAPHOR (Reddy 1993), where an abstract discourse object is visually reified as something concrete (Cienki 2005; Streeck 1994).

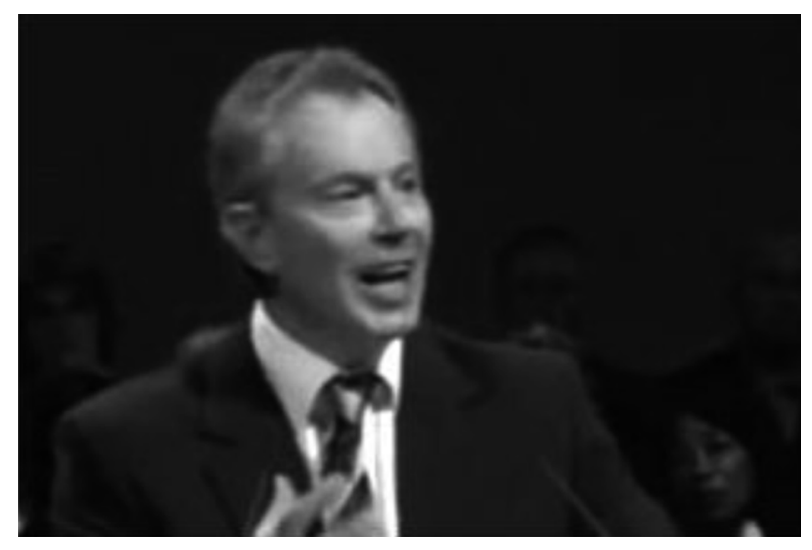

Figure 10: Blair's gesture on "the values themselves"

Then, on devalued, his two palms facing each other are re-mobilized; they are still facing each other, but this time they are flat with fingers extended as they move downward and away from Blair. The negative prefix de- in devalued is visually rendered by this metaphoric gesture where hand orientation and hand movement are clearly instantiating the basic metaphors DOWN IS LESS and DOWN IS BAD. The initial discourse object is thus recategorised as a meta-referential gesture used to evaluate the political elements mentioned by Blair at the time of speaking, thereby reinforcing Blair's threat thanks to a carefully organized multimodal strategy. 


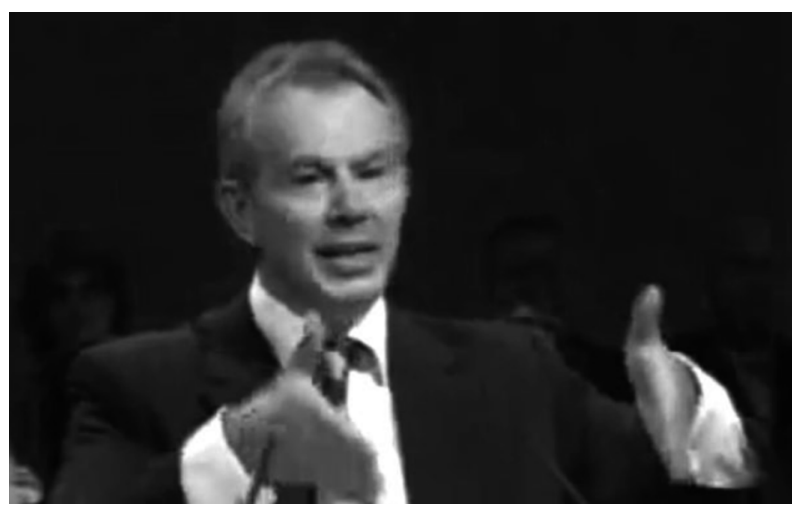

Figure 11: Blair's gesture on "become devalued”

We have thus shown that the text - and ensuing code - selected for party conference speeches aim at creating a privileged stage for the leader and the party. This is achieved (i) by focusing on political momentum rather than on political analysis; (ii) by emphasising elements of the party's policy choices that are highly symbolic and/or non-controversial; (iii) by bringing to the foreground the party's values and the quintessence of the party's brand.

\section{Conclusion}

This paper has proposed to account for the specificities of the party conference speeches as a political genre event. We have taken up the "methodological synergy" propounded by Baker et al. (2008: 274), as well as Steen's call for a "multifeaturemultidimensional model" (2011: 37), in order to design a multimodal approach to the genre event of party conference speeches. It combines quantitative and qualitative analyses of an extensive collection of texts with an in-depth study of Tony Blair's 2006 party conference speech, for which we analyse the written text, the gestural and intonational patterns associated with its delivery, and the rhetorical strategies the speaker relies on.

We have chosen to adopt a socio-cognitive approach to genre, borrowing from Steen (2011), Bateman (2008) and Goffman (1986). Our approach presents context as the reason for existence of the genre event. This has also allowed us to make sense of various borrowings from other genre events (political or not) following Garzone and Ilie's definition of hybridisation (2014). We have identified two main patterns for party conference speeches. First, we have argued that the different layers of context for party conference speeches determine 
which code will provide enough evidence that the genre is being enacted. The leader's party conference speech characteristically refers to its circumstances of production and to the wider institutional ritual of the party conference. It is a speech that builds an atmosphere of 'structured informality' with the audience(s) through a series of rhetorical strategies and specific rhetorical moves. It emphasizes the fundamentally dialogical dimension of political speeches (Feldman and Bull 2012) in order to fulfil a series of strategic and political goals. An image of unity is created by rejecting debate from the speech and its context, and favouring consensus over the speaker's words. Second, the text selected for party conference speeches (and its ensuing code) aims at creating a privileged stage for the leader and the party. The speaker generates more political momentum than political analysis. He highlights elements of the party's policy choices that are highly symbolic and/or non-controversial. Finally, he brings to the foreground the party's values and the quintessence of the party's brand.

\section{References}

Archer, Dawn (ed.). 2009. What's in a Word-List?: Investigating Word Frequency and Keyword Extraction. Farnham, England \& Burlington, VT: Ashgate PubLtd.

Aristotle. 350AD. "Rhetoric." Translated by W. Rhys Roberts. The Internet Classics Archive, Massachussetts Institute of Technology. http://classics.mit.edu/Aristotle/rhetoric.1.i.html.

Baker, Paul. 2004. "Querying Keywords: Questions of Difference, Frequency, and Sense in Keywords Analysis." Journal of English Linguistics 32(4): 346-59.

Baker, Paul. 2006. Using Corpora in Discourse Analysis. London: Continuum.

Baker, Paul, Costas Gabrielatos, Majid KhosraviNik, Michał Krzyżanowski, Tony McEnery, and Ruth Wodak. 2008. A Useful Methodological Synergy? Combining Critical Discourse Analysis and Corpus Linguistics to Examine Discourses of Refugees and Asylum Seekers in the UK Press. Discourse \& Society 19(3): 273-306.

Bateman, John. 2008. Multimodality and Genre: A Foundation for the Systematic Analysis of Multimodal Documents. Basingstoke \& New York: Palgrave Macmillan.

Bavelas, Janet Beavin, Nicole Chovil, Linda Coates, and Lori Roe. 1995. "Gestures Specialized for Dialogue." Personality and Social Psychology Bulletin 21(4): 394-405.

Benveniste, Emile. 1966. Problèmes de Linguistique Générale. Paris: Gallimard.

Bhatia, Vijay. 2014. Worlds of Written Discourse. London: Bloomsbury academic.

Biber, Douglas. 1988. Variation across Speech and Writing. Cambridge \& New York: Cambridge University Press.

Boersma, Paul, and David Weenink. 2015. Praat: Doing Phonetics by Computer [Computer Program] (version 5.4.08). http://www.praat.org/.

Bolinger, Dwight. 1983. Intonation and Gesture. American Speech 58(2): 156-74.

Bradley, A. Smith, K. O'Halloran, Alexey Podlasov, and Victor Fei. 2014. Challenges and Solutions to Multimodal Analysis: Technology, Theory and Practice. In Fang Yan and Jonathan J. Webster (eds.) Developing Systemic Functional Linguistics: Theory and Application, 27197. Sheffield, UK \& Bristol, CT: Equinox Publishing. 
Brown, Penelope, and Stephen C. Levinson. 1987. Politeness: Some Universals in Language Usage. Cambridge \& New York: Cambridge University Press.

Cienki, Alan. 2005. Image Schemas and Gesture. In Beate Hampe and Joseph Grady (eds.) From Perception to Meaning: Image Schemas in Cognitive Linguistics, 421-42. Berlin \& New York: Mouton de Gruyter.

Debras, Camille, and Emilie L'Hôte. 2015. Framing, Metaphor and Dialogue - a Multimodal Approach to Party Conference Speeches. Metaphor and the Social World 5(2).

Faucher-King, Florence. 2005. Changing Parties: An Anthropology of British Political Party Conferences. Basingstoke: Palgrave Macmillan.

Feldman, Ofer, and Peter Bull. 2012. Understanding Audience Affiliation in Response to Political Speeches in Japan. Language and Dialogue 2(3): 375-97.

Finlayson, Alan, and James Martin. 2008. 'It Ain't What You Say. . .': British Political Studies and the Analysis of Speech and Rhetoric. British Politics 3(4): 445-64.

Garzone, Giuliana, and Cornelia Ilie. 2014. Genres and Genre Theory in Transition. An Introduction. In Giuliana Garzone \& Cornelia Ilie (eds.) Genres and Genre Theory in Transition: Specialized Discourses Across Media and Modes, 7-15. Boca Raton, Florida: BrownWalker Press.

Goffman, Erving. 1967. Interaction Ritual; Essays on Face-to-Face Behavior. Garden City, N.Y.: Anchor Books.

Goffman, Erving. 1986. Frame Analysis: An Essay on the Organization of Experience. Boston: Northeastern University Press.

Heritage, John, and David Greatbatch. 1986. Generating Applause: A Study of Rhetoric and Response at Party Political Conferences. American Journal of Sociology 92(1): 110-57.

Horton, Donald, and R. Richard Wohl. 1956. Mass Communication and Para-Social Interaction: Observations on Intimacy at a Distance. Psychiatry 19: 215-29.

Kendon, Adam. 2004. Gesture: Visible Action as Utterance. Cambridge, UK \& New York: Cambridge University Press.

Kessler, Brett. 2001. The Significance of Word Lists. Stanford, CA: CSLI Publications.

Lakoff, George. 2002. Moral Politics: How Liberals and Conservatives Think. Chicago: University of Chicago Press.

L'Hôte, Emilie. 2010. New Labour and Globalization: Globalist Discourse with a Twist? Discourse \& Society 21(4): 355-76.

L'Hôte, Emilie. 2014. Identity, Narrative and Metaphor: A Corpus-Based Cognitive Analysis of New Labour Discourse (1994-2007). Basingstoke: Palgrave Macmillan.

L'Hôte, Emilie, and Maarten Lemmens. 2009. Reframing Treason: Metaphors of Change and Progress in New Labour Discourse. CogniTextes, Varia, Volume 3 (December). http://cognitextes. revues.org/248.

Louw, M. 1993. Irony in the Text or Insincerity in the Writer? The Diagnostic Potential of Semantic Prosodies. In Mona Baker, Gill Francis, Elena Tognini-Bonelli, and John Sinclair (eds.) Text and Technology: In Honour of John Sinclair. Philadelphia: John Benjamins.

Mair, Peter. 1994. Party Organizations: From Civil Society to the State. In Richard S. Katz \& Peter Mair (eds.), How Parties Organize: Change and Adaptation in Party Organizations in Western Democracies, 113-35. London \& Thousand Oaks: Sage.

Mariot, Nicolas. 2006. Le Frisson Fait-Il La Manifestation? Pouvoirs, 1: 97-109.

Mariot, Nicolas. 2009. Le Paradoxe Acclamatif, Ou Pourquoi Les Institutions N'ont Pas de Première Fois. In François Buton \& Nicloas Mariot (eds.) Pratiques et Méthodes de La Socio-Histoire, 169-190. Paris: Presses Universitaires de France. 
McNeill, David. 2005. Gesture and Thought. Chicago: University of Chicago Press.

Meyer, Charles F. 2002. English Corpus Linguistics: An Introduction. Cambridge \& New York: Cambridge University Press.

Minkin, Lewis. 1978. The Labour Party Conference: A Study in the Politics of Intra-Party Democracy. Allen Lane.

Montgomery, M. 1999. Speaking Sincerely: Public Reactions to the Death of Diana. Language and Literature 8(1): 5.

Morel, Mary-Annick, and Laurent Danon-Boileau. 1998. Grammaire de L'intonation: L'exemple Du Français Oral. Paris: Ophrys.

Mouffe, Chantal. 1998. The Radical Centre - a Politics without Adversary. Soundings 9.

Müller, Cornelia. 2004. Forms and Uses of the Palm Up Open Hand: A Case of a Gesture Family?” In Rolland Posner and Cornelia Müller (eds.) The Semantics and Pragmatics of Everyday Gestures: Proceedings of the Berlin Conference, April 1998, 233-56. Weidler: Buchverlag.

OAD. 2009. Oxford American Dictionary and Thesaurus. 2nd ed. Oxford \& New York: Oxford University Press.

Oakes, Michael P. 1998. Statistics for Corpus Linguistics. Edinburgh: Edinburgh University Press.

Pettitt, Robin T. 2012. Me, Myself and I: 'Self-Referencing' in Labour Party Conference Leaders' Speeches. British Politics 7(2): 111-34.

Rayson, Paul. 2003. Matrix: A Statistical Method and Software Tool for Linguistic Analysis through Corpus Comparison. Unpublished Doctoral Thesis, Lancaster University, Lancaster.

Rayson, Paul. 2008. From Key Words to Key Semantic Domains. International Journal of Corpus Linguistics 13(4): 519-49.

Rayson, Paul. 2009. Wmatrix: A Web-Based Corpus Processing Environment. Computing Department, Lancaster University. http://ucrel.lancs.ac.uk/wmatrix/.

Reddy, M.J. 1993. The Conduit Metaphor: A Case of Frame Conflict in Our Language about Language. In Andrew Ortony (ed) Metaphor and Thought, 2nd ed. Cambridge: Cambridge University Press.

Sinclair, John. 1991. Corpus, Concordance, Collocation. Oxford: Oxford University Press.

Steen, Gerard J. 2011. Genre between the Humanities and the Sciences. In Marcus Callies, Wolfram R. Keller, and Astrid Lohöfer (eds.) Bi-Directionality in the Cognitive Sciences: Avenues, Challenges, and Limitations, 21-42. Amsterdam \& Philadelphia: John Benjamins.

Streeck, Jürgen. 1994. "Speech-Handling": The Metaphorical Representation of Speech in Gestures. A Cross-Cultural Study. Austin, Texas: Unpublished PhD dissertation.

Streeck, Jürgen. 2009. Gesturecraft: The Manu-Facture of Meaning. Amsterdam \& Philadelphia: John Benjamins.

Sweetser, Eve. 1990. From Etymology to Pragmatics: Metaphorical and Cultural Aspects of Semantic Structure. Cambridge: Cambridge University Press.

Sweetser, Eve, and Barbara Dancygier. 2005. Mental Spaces in Grammar: Conditional Constructions. New York: Cambridge University Press.

Thibault, P. J. 2000. The Multimodal Transcription of a Television Advertisement: Theory and Practice. In Anthony Baldry (ed.) Multimodality and Multimediality in the Distance Learning Age: Papers in English Linguistics, 311-85. Campobasso: Palladino.

Wittenburg, P., Brugman, H., Russel, A., Klassmann, A., Sloetjes, H. 2006. ELAN: a Professional Framework for Multimodality Research. In Proceedings of LREC 2006, Fifth International Conference on Language Resources and Evaluation. http://www.lat-mpi.eu/tools/elan/ download 